\title{
I Want Your Vote: The Real Campaign Continues
}

\author{
Steven N. Handel
}

M y Fellow Citizens, my name is Restoration Ecologist, and I'm running for office! I'm the perfect candidate for you and the public issues that are most important to you!

\section{I'll keep taxes low!}

Tired of expensive infrastructure and public works that have been consistently used as engineering solutions? Tired of high labor costs for grounds maintenance and for oldstyle erosion control practices? Let me install natural habitats and bioengineering to do the job! Done right, they minimize public landscape construction costs and keep that tax rate down. Let my new habitats help maintain and clean the groundwater, instead of building another water filtration plant. Let me help cool and clean the air, cutting your air conditioning needs. A green roof means green in your pocket as well as green over your head. Let my new woodlots shade your homes and public buildings, saving even more on energy costs as well as giving beauty. Let my meadows increase pollinator populations to advance agricultural production, lowering farm subsidies and increasing yield margins for farmers. Long-lived, low-maintenance habitats in our communities can allow us to cut tax rates or use the saved funds for other critical social needs. Restoration is more than habitats. It's also restoration of a sane fiscal policy.

\section{I'll keep health costs down!}

Too many sick kids, too many struggling seniors! We need a healthier environment! The huge numbers of public health problems in our cities are amplified by heat load, ozone, and dirty air. Let my Green Streets programs improve the air column and cut back on these health menaces. My green spaces and small neighborhood parks lead to stress reduction and better mental health for our communities. Tense at the workplace, intense at home? Hard to concentrate at school? Take a walk on the wild side; calm down, thanks to Restoration Ecology, your partner for a happier day at the office and at school. A healthy family is a happier family, and it starts with our local environment; I'm there to help!

Ecological Restoration Vol. 31, No. 1, 2013

ISSN 1522-4740 E-ISSN 1543-4079

C2012 by the Board of Regents of the University of Wisconsin System.
I'm good for business, Wall Street AND Main Street!

Let's keep those corporate profit margins up by cutting down on facilities maintenance costs. Money saved on landscape operating costs can be fed into innovation initiatives and expanding market share, building our companies. Restore tidal wetlands and vegetated dunes and your upscale coastal developments will be better protected from storms like Hurricane Katrina and Superstorm Sandy. Your new construction of marinas, coastal resorts, and residential areas will go up in value with increased protection. Your insurance policy costs will go down. I'm the capitalists' best friend. Small businesses will profit too. Shoppers prefer retail zones that are green and lovely, that welcome people tired of the rush and crowds and cookie-cutter feel of big malls in downtown concrete business districts. Pedestrian malls all over our great country are models of successful business practices. Add bioswales with babbling brooks and leafy shade and watch those shoppers move in. Restore your community's natural beauty, then listen to those cash registers jingle as the birds sing!

\section{I'm for social justice!}

Former industrial areas, abandoned old downtowns, boarded-up storefronts: these are the areas where our at-risk populations huddle, hopeless, often ignored, and lacking any real chance of social mobility. Try a green solution: community supported agriculture, pocket parks, neighborhood greening using young people trained with salable environmental skills. Adding relatively low-cost landscape rather than new high cost construction at community centers with low occupancy can change the fate of our poor neighborhoods. Let's make them appealing again to folks wanting to come back to our old city centers and build population density where there has been blight. The pollution of the past can be remediated and replaced with modern restoration techniques. Instead of watching those decaying and empty parking lots crack and crack each year, let's plant them up and add value to our poorest inner-cities. I'm Restoration Ecologist, and I'm for urban areas too, not just the country side.

I'm pro-family! I'm for youth AND I'm for seniors!

No matter what your heartfelt beliefs are towards family planning and when human life commences, we all want a 
nurturing and positive lifestyle for our youngest children to help them as they start their lives' journeys. Restoring the invaluable ecological services around our young children supports and celebrates the sanctity of life in the most profound way. Let me join with you all to protect young children and build their quality of life from their very first moments. The process of restoration can include the warmest of family activities, building community spirit as well as intergenerational goodwill. So many local restoration projects involve scouts, students, strivers, and seniors. Work teams can include people of every age class learning together and improving our communities. We live in a world of tremendous divisions among generations. Restoration projects can pull us all together for the common good. Support life, through the whole life cycle!

\section{I'm a favorite of religious institutions!}

Almost all religions have texts and holidays that honor our environment and all of God's creation, no matter how one defines the eternal. The western Bible, Old and New Testaments, is suffused with instructions to be good stewards of all creation. Even the instruction in the Garden of Eden, "have dominion over . . . every living thing," is often interpreted as a call and requirement to sustain all life, what we now term conservation and restoration. There are "Green Bibles" published that highlight these many environmental passages. Eastern religions also mesh religiosity with environmental honor and obligation. There are holy forests in India, spiritually protected landscapes in China and Japan, the Jain tradition that guards all living things, and grand ancient landscapes which are treasured by Aboriginal Australians. To my fellow citizens with deep religious views, let me be your partner. Together we will protect what is precious to you in your heart; I with my ecological know-how, you with your deep devotion and spiritual motivations.

\section{I’m against crippling regulations!}

Restoration progress when done well only needs the lightest bureaucratic touch over the coming years. Monitoring must be done against immediate environmental threats, but a well planned and executed restoration project is selfsustaining. The more modern green infrastructure we use the less we depend upon technically complex infrastructure which must be micromanaged and financially supported year after year. Sustainability is the outcome of properly completed restorations, less so of mechanical solutions that need operating manuals and regulatory supervision.

\section{I'm for a strong national security!}

I believe in the broadest definition of national security and want to keep this country strong in every way. This means protecting our shorelines from storm surges, protecting our drinking water supply, eliminating pollutants and recharging our aquifers to keep water quantity high. I believe in food security by curtailing soil erosion and having stronger local agricultural production around our population centers to cut transportation costs and bring fresh healthy food to even our poorest neighbors. This gives them a better change of contributing to our national future. I believe in unpolluted air and in biocontrol of pests so that chemicals don't damage our health and ability to keep building our country. I'm not just planting trees and flowers; I'm planting a foundation for a secure future so we are able to minimize environmental threats to our preferred way of life.

\section{I'm for balancing the budget!}

Every level of government, from your town to your country, struggles to match revenue with expenses. Each restoration project is an investment in our future, not an expense. As we move from land uses that require constant maintenance and upkeep and repair to self-sustaining habitats, from green streets to pocket parks to green corridors on abandoned railways, we're finding ways to limit future expenses that we all must pay for from tight, tight budgets. All my neighbors in coastal areas now know that strong restored habitats will parry the devastation of storms and keep rebuilding costs way down. Vegetated dunes and seagrass beds help shorebirds and marine life, but also help dry up tears from heartbroken coastal residents. I'm interested in economy as well as ecology. I'll bring that perspective to every decision I make on the ground.

\section{I'm pro-environment!}

Restoring species' populations builds local biodiversity and gives us habitat resilience and protection from the many dangers of climate change. The more species we have, the greater the chance that ecological function will continue and those ecological services will persist. Presence of higher biodiversity is not just for a new species name to be checked off on your life list; the restored species build ecological redundancy and stability in the stressful environment that's rushing down the tracks towards us. Also, each part of our environmental mosaic is connected with the next one: healthy woodlands are drained by clean streams that transport carbon resources to our rivers and lakes. These then nurture our estuaries and oceans, building coastal fisheries that support jobs and a healthy marine food web. Know the story of salmon swimming in from the ocean, spawning in shallow streams? Bears and other carnivores catch and eat many dying fish. The droppings of these animals reach the surrounding forest, bringing back nutrients and carbon sources to fertilize the woodlands where the cycle began. Each time we restore a piece of the mosaic the whole ecological structure gets stronger. Restoration is the partner of conservation in a wounded world. 
I love our country; no one's more patriotic!

How proud we are of our natural heritage. There is a special "sense of place" that each part of our country honors for its regional character and beauty. We tout our special areas from National Parks and National Natural Landscapes to our County Parks. These remind us of the landscapes used and enjoyed by Native Americans and by the first settlers from across the seas; they help make the past come alive into the present. Ecological restoration keeps these special places functioning and keeps our landscape visible to inform the future. I also have a fine reputation for trying to eliminate invasive species of plants and animals. They're sweeping across the landscape, changing ecological conditions and crowding out our native species. We want that habitat space and its resources for native species that are the best chance to support our national landscape character and persistence. That old Woody Guthrie song touts our national bounty, "From the redwood forest to the Gulf Stream water . ..." not our kudzu and English Ivy vines and thickets and our degraded streams. Let's burnish our living heritage; let Restoration Ecology help!

\section{I'm for world peace!}

Tensions in the world build when people run out of a source of clean water, firewood, productive soil and food supplies. Tensions lead to war and our country so often gets dragged in with its blood and treasure. Let me help solve these international crises by restoring woodlands to bind soil, provide fuel wood, and recharge waterways. Let me restore meadows that buffer against invasives and build pollinator communities for high crop yield. Let me help secure the unusual and compelling distant landscapes to build the many advantages of ecotourism. This advances understanding among peoples and economic progress for the poor regions of the world. Environmental restoration goes hand-in-hand with industrial and educational progress to improve the lot of people in all those poor countries. The more they improve, the more we have markets for our own goods and services and the more they are tied in with our economic fate. This builds friends across borders and mitigates against the chance of military conflicts. Let's keep the world safe for the next generation through strategic ecological restoration.

Yes, my Fellow Citizens, I'm the candidate for you, ALL of you.

What am I running for, you ask? I'm running for the local town council and the environmental commission, and to be the Mayor. I'm running for the state legislature and the governor's mansion. I'm running for the federal legislature, House and Senate. And, yes, I am running to be your President. In your community, your state, or across the country, my policies are what we must try, at all levels.

Wherever there's a social crisis, economic pain, environmental damage, or ethical need, I, Restoration Ecologist, can help you solve the problem. I want to be there for you. Let me work for you. I want your vote! 